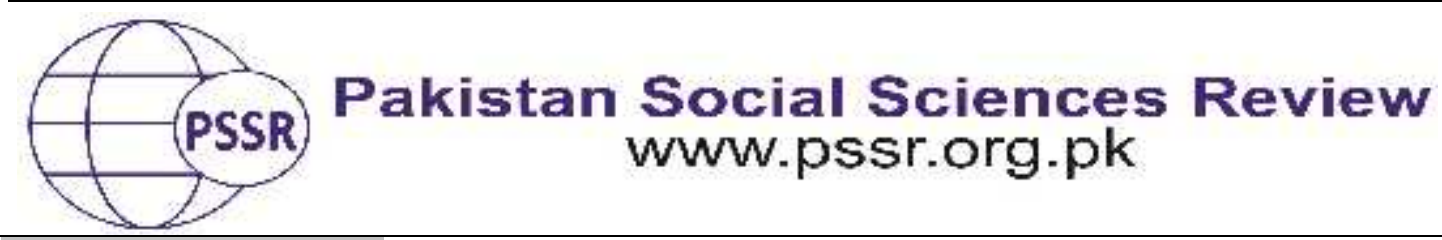

RESEARCH PAPER

\title{
Maritime and its Significance in National Economy
}

\author{
Dr. QamarAbad ${ }^{1}$ Dr. Ghulam Murtiza²
}

1. In-charge Ph.D. Program, School of Law, University of Karachi, Sindh, Pakistan

2. Assistant Professor, College of Law, Government College University, Faisalabad, Punjab, Pakistan

\begin{tabular}{|c|c|}
\hline & \\
\hline & \multirow{18}{*}{$\begin{array}{l}\text { The aim of this article includes identifying the maritime sector } \\
\text { and its activities in Pakistan's commercial and corporate centers. } \\
\text { This article is based on descriptive research and vast experience } \\
\text { at sea and in maritime sector worldwide of the first author and } \\
\text { the second author's educational and academia skills and } \\
\text { expertise. Despite having a coastal belt of more than } 1000 \\
\text { kilometers and having considerable number of seafarers } \\
\text { performing high profile tasks on foreign ships and shore } \\
\text { establishments abroad, awareness of maritime affairs in Pakistan } \\
\text { is miserably at the lowest level tending to negligible. General } \\
\text { view of maritime activities limits to the port activities and } \\
\text { Pakistan National Shipping Corporation having ships in single } \\
\text { figure. In fact the maritime sector is wider enough to cover } \\
\text { majority of commerce and businesses. International commerce } \\
\text { and trading which is back bone of economy of a country mainly } \\
\text { depends upon maritime activities. It is indispensable to educate } \\
\text { people of Pakistan and officials through publications and other } \\
\text { means to utilize the maritime resources available but ignored. } \\
\text { The authors through this article endeavor to introduce } \\
\text { awareness of one of the most vital areas of the economy. }\end{array}$} \\
\hline & \\
\hline & \\
\hline & \\
\hline & \\
\hline & \\
\hline & \\
\hline & \\
\hline & \\
\hline & \\
\hline & \\
\hline & \\
\hline & \\
\hline & \\
\hline & \\
\hline & \\
\hline & \\
\hline & \\
\hline
\end{tabular}

\section{Introduction}

For the purpose of introducing with better understanding and clarity, it seems necessary to start with very basic concepts of one of the most important areas of international commerce, trade and business for the development of national integrity and economy. This area despite on the priority list of the developed as well as some developing nations is still ignored in other developing countries including Pakistan. Such ignorance among other factors is primarily due to unawareness of the benefits which can be achieved from developments and investments in the area named 'maritime'. This discrepancy ultimately results in lack of mechanism necessary for utilization of the maritime resources in the best interest of the people. Despite having a coastline of more than a thousand kilometers, Pakistan could not include itself among maritime nations. Unfortunately, due to unawareness and lack 
of education, it appears that neither the true meanings of the word 'maritime', nor its location have been traced or realized. It has been commonly noticed with regret that a common understanding of the term 'maritime' among the people responsible in the relevant fields is limited tothe capacity of national flag (sea) carriers and number of ships owned by them, activities of ports and terminals, fishing etc. Whereas, the fact is that 'maritime' is not limited to a number of coastal activities mentioned above as viewed generally but it extends enormously beyond that and is embedded in every commercial and business activity to varying extents. International commerce and trade is mainly carried out through sea or it involves sea passage partly, is well included in 'maritime'. The introduction of modern 'container revolution' and 'multi-modal transportation' has extended the scope of 'maritime' beyond sea and waters to include the land deep inside a country where goods are conveyed or shipped from. It has changed the entire scenario of the commerce, business and trade. In order to grasp the benefits available from the field, basic awareness and its understanding at first step and then the knowledge of relevant laws especially the 'international law' and the 'law of the sea' laid down in the (UNCLOS) 1982 are necessary. The expertise and resources are widely scattered and required to be located, identified and organized for beneficial utilization. Such exercise requires relevant education in the field by experts having knowledge and experience. Study in the field of international law of the sea or UNCLOS-1982 is strategically the need of the country to protect against any offensive and catering it at the international forums if a situation is imposed.

\section{Literature Review}

The word "maritime" means, 'of the sea or pertaining to the sea', in Latin, the term, 'maritimus' from which the word 'maritime' is derived, refers to the activities in connection with sea, rivers, and waters connected therewith used or capable of being used for sea navigation and sea commerce including the sea shores and areas nearby (Garner, 2004).It may be elaborated further that in its appropriate meanings, it includes matters relating to the sea in a broader sense of activities on the high seas, on the shores or coastal areas and inland waters, lakes, rivers and estuaries where navigation and commerce takes place. Also sea in this context is not limited to high seas and oceans but it refers to all kinds of navigable waters independent of tidal phenomenon or tidal flow (Benedict, 1940).

Maritime, even traditionally, is not restricted to oceans and seas but it includes all navigable waters, used or capable of being used for sea navigation. The purpose of navigation is mainly the commerce or commercial activities of transportation of goods or passengers from one place to another in a safe manner for earning reward in terms of freight or fare as appropriate. Naval warfare, exercises and operations, also involve high skilled navigation and are among the maritime activities. Additionally, a number of activities carried out ashore and far away from sea or navigable waters are included in the maritime activities e.g. dry ports, warehousing, freight forwarding, packaging, legal actions against maritime claims, marine insurance, chartering and ship-brokering etc. 


\section{Maritime Commerce, Sea and Ship}

Maritime commerce traditionally requires two elements necessarily, sea and ship. Sea is in co-existence with the planet and life on it and has many usages and benefits for mankind and other creatures in existence on it. Marine life which brings sea food and a number of other benefits is dependent upon the existence of sea. About three-quarter of the planet is covered by seas which regulates the climates, brings weather changes and rains without which the life on the planet may have no possibility of existence. Our concern at this point is the importance and the role of sea in maritime commerce and not its benefits in general.

The term 'sailing' traditionally used with movements of ships at sea is not limited to mean a ship being moved or driven by sails but it generally refers to the movement of ships at sea. Ships and their sailings have been instrumental in development and progress of civilizations. The movement and conveyance, especially of goods on water has always been greater in quantity than on land. Transportation of passengers at sea has greatly been developed from carriage of passengers on decks, exposed to whether and waves to under decks in shelters and in safer and comfortable positions on board ships. The developments in the industry are evident from the availability of safe, comfortable, and luxurious passenger ships presently employed as cross channel ferries and ocean going passenger cruisers across the globe. Similarly a variety of cargo ships with highest standards of safety and facilitations are another example of developments in the maritime sector.

\section{Use of Watercrafts}

Waterborne crafts and boats have been traced being in existence as early as 4000 B.C. Historical evidence of boats in existence have been found in Egypt during $4^{\text {th }}$ millennium B.C. Ancient Egypt was mainly inhabited along the Nile and supported by it (Britannica, 1993). Human by nature and in need of food and other necessities of life always tend to inhabit near water resources. Naturally, for making the best use of water resources available, human tendency leads to conquer the water for beneficial use by employing things which either float and may support other things to float on water like wooden logs, packed canes or bamboos, dugout stems or stones, and similar materials could be used as a raft capable of floating in water and propelled by hands or oars or other means.

Early as the Egyptians and Mesopotamian civilizations were famous for making beneficial use of waters near their inhabitations. They appear to have made more use of rivers and estuaries in comparison with sea. They were famous for sailing their water crafts and boats for transportation of goods and people on the rivers. The Nile, Euphrates and Tigris were the most commercial rivers for transportation of goods and passengers. The Nile being the most favorable for navigation by virtue of its predictable winds and streams suited the Egyptians for transportation. In the Nile, winds mainly blow from north to south and unidirectional currents from south to north with varying intensity. The predictable 
winds and currents enable ships under sails and oars to plan a passage economically by gaining ample speed and better steerage by utilizing the winds and stream favorably. The exact time when mankind learned the techniques and the art of constructing a water craft capable of floating on water as means of conveyance could not be traced accurately from history and remains immemorial. However, there are evidences of floating crafts in existence and transportation of human and goods prehistoric.

\section{Ship and Vessel Distinction}

As per section 2(k) of Admiralty Jurisdiction of High Courts Ordinance 1980 and section 8 (i) of Administration of Justice Act 1956, ship includes any description of vessel used in navigation. And according to section 3(56) of General Clauses Act 1897, a vessel shall include any ship or boat or any other description of vessel used in navigation. For a floating structure to be a vessel or ship, it should be navigable; and capable to encounter perils of sea having characteristic of a vessel. In simple, every vessel for the purpose of maritime laws cannot be regarded as vessel or ship unless it is capable of being navigable in water (which includes steering capability and means as well) and capable to safely encounter the usual perils of the sea. In other words, only the ability to float, would not entitle an object as a vessel or ship but it necessarily requires being navigable and safe against the perils of the sea.

\section{Delisting and Demolition of Sips-Effects}

Delisting of a vessel from the registry of its flag state would not alter her character of the vessel or render her as non-navigable. However, her demolition or dismantling to an extent rendering her non-navigable would reduce her to nonvessel with respect to the provisions of the statutes (Azhar Ahmad Khan and Others v. M.V. Ashar and 3 Others, 1985). Demolition to considerable extent means her physical demolition to an extent rendering her unserviceable as a vessel. Thus a vessel under detention, arrest or being laid up shall remain a vessel or ship under law.

\section{Ancient Ships and Boats}

Ships and boats are used on lakes, rivers, sea and other waters for various activities, such as transporting people and goods, fishing, entertainment, public safety, exploration, researches, experiments, and warfare. During earlier ages, a ship was distinguished from a boat by its masts. In English traditions, a ship is referred to as "SHE" without any regard to her name.

A ship or boat undergoes through various stages of designing, construction and launching before being manned and put into desired service(s). The ships are designed and constructed keeping in view the intended services. Financing is another important aspect of the ships' construction. In the modern age ships prior to their construction may be chartered by demise under special agreements. The ownership of a ship may become complex at times especially when she is put into 
service and hired (chartered) for use. In addition to her registered owners, she may have bareboat or demise charterers, time or voyage charterers, sub-charterers, operators, managers which makes the identification of her beneficial ownership greatly difficult to identify. For dealing with such issues a ship itself has been rendered an entity and in being in jurisdiction of a court with competent jurisdiction becomes open to sue for a variety of claims arising against it and the owner.

A ship from her designing stage to the completion of her construction and thereafter being put into service is strictly monitored for compliance with the minimum standards of construction and safety in accordance with the international and national standards and criterion set by the country where she is to be registered. The design of a ship is submitted before the administration of the country where the ship is desired to be registered. The administration in Pakistan, Mercantile Marine Department (MMD), Directorate General Ports \& Shipping, Ministry of Maritime Affairs, after verifying compliance with the rules of construction, may approve the design or send it back for necessary amendments if required. Similarly, all the maritime nations have their respective departments assigned the responsibility and powers in this respect. The verification of the design is done in accordance with the requirements enumerated in the Ship Construction Rules under the provisions of the relevant statutory requirements. In Pakistan, the Pakistan Merchant Shipping Ordinance 2001 contains the necessary provisions of law and rules of construction for ships of various kinds. Other countries have their own rules of ships construction in respective enactments. The entire process of construction is monitored under the supervision and control of the administration. The monitoring of ship designing, construction and regulating its operations involve high skills and expertise and in practice are generally delegated to reputed 'classification societies'.

\section{Developments in Ships' Construction and Subdivisions}

Similarly, developments in the carriage of goods by sea achieved the highest standards in quantitatively as well qualitative including the safety standards. In the beginning only single deck wooden ships were in use. Goods on open decks were generally exposed to sea resulting in serious safety issues including risks to life and property on board (question of risks to environments had not arisen then). Goods frequently damaged due to heavy weather, waves and sea sprays on decks, and capsizing, grounding and sinking of ships were common. Even under deck and sheltered spaces were not safe as required or weather-tight in the popular sense. Washing away and jettisoning of goods including slaves were common in perils at sea. Voluntary jettisoning of goods for lightening the ship when taking in water or damaged by heavy weather or fire to avoid the spreading of fire or giving part or all of the cargo in ransom to pirates or local lords were common in trade by sea. Slaves would be jettisoned as goods on board. However, with passage of time and use of steel in shipbuilding, new designs of ships were introduced with various decks and weather-tight under deck spaces (compartments). It enabled the ships to stow their cargo under deck and well protected from weather and waves. The introduction of 
subdivisions in the construction of ships played a revolutionary role in safety of life and property at sea. The subdivisions in a ship enabled her to design watertight compartments capable of being segregated from other compartments. The technique contributed considerably in improving water-tightness in hull, machinery and other compartments as well as extra strengthening of ship's structure. In case of accidental damage and ingress of water or flooding of one of the compartments (bilged), the others would remain intact and un-flooded. This technique in naval architecture effectively controlled the risks of flooding and controlling any ingress of water into the ship. Consequently, the cargo spaces popularly called cargo holds could be made weather-tight. Weather tightness differs from water tightness in the way that the former protects against the ingress of water into the compartment but the later the both in and out. The cargo compartments or spaces are necessarily required to be made weather-tight.

\section{Various Kinds of Ships}

Various kinds of ships with respect to the means of propulsion are in service for example, a rowing ship is the one maneuverable in water by oars (galley is one example), a sailing ship powered by the force of wind through its sails (provided that propelling machinery if fitted is not being used) and power driven vessel (ship) being propelled by machinery (International Regulations for Preventing Collisions at Sea, 1972, Rule, 3(b) \& 3(c)). A "Powership" or "Power-ship" however, is different from a power driven ship or vessel (Lakhra Power Generation Company Limited (LPGCL) v. Karadeniz Powership Kaya Bey, 2014).

Special ships are designed in view of the cargoes intended to be carried. Oil tankers are designed to carry liquid oils in bulk including petroleum products, crudes, edible oils and other products of the kind. Gas carriers for carriage of natural and petroleum gasses i.e. LNG (Liquefied Natural Gas) and LPG (Liquefied Petroleum Gas) tankers, Bulk carriers for dry bulks, Ore carriers to carry ores, OilBulk-Ore (OBO) carriers, Container carriers etc. The developments in the field of ship-construction achieved the highest standards of safety and rapid transportation of passengers and goods. The sea passages have become safer and risks of losing or damage to ships or cargo at sea have minimized greatly.

The safe and efficient carriage of passengers and goods across oceans primarily improved confidence of passengers and merchants. Secondarily, the maritime legislations thereby necessary for smooth and fair trade which developed from the customary practices in the trade by sea played an important role. Availability of remedies against any breach of contractual obligations or legal duties played vital and significant roles in building the confidence of passengers, merchants, shippers and buyers of the goods. 


\section{Arabs and Egyptians in Maritime}

Ancient Arabs and Egyptians had been in maritime and trade by land, sea and inland waters including rivers on a large scale in their respective regions and their neighborhoods. Phoenicians are said to be succeeding the Egyptians in commerce, trade and maritime affairs in the Mediterranean region. But no traces or evidence in written form have been found which could lead to the existence of any codified maritime practices or customary law. However, people of Rhodes made major contributions in codification of maritime practices and laws shows that Island of Rhodes was the Centre of maritime commerce and trade before Christian era around 900-800 BC, and Roman Empire. The fact is clearly acknowledged and mentioned in the passages from the Justinian Digest (ad 533) of Justinian-I, the Roman Emperor. The first quote referred to the emperor Antonius (138-161 AD) deciding a case of plunder resulting from a ship-wreck. By declaring his sovereignty on the world as the lord, observes the law as the lord of the sea. He decides that the matter before him must be decided by the Rhodians' maritime law provided it does not conflict with the Roman law (Britannica, 1993).

The second example is the "Lex Rhodia de Jactu" also termed "Rhodian law of the Sea for Jettisoning" included in the Digest with retention of its name which forms basis of the modern law of general average (Flower, 2014). The law of general average with the same spirit as from its inception provides for equitable contributions from all the parties benefitting from a volunteered sacrifice to save the adventure. In the beginning it was limited mainly to the jettison of goods (including slaves) from the ship to save it from sinking or grounding. However, later it was extended to other incidents including expenses and delays from calling a port of refuge for necessary repairs, cargo handling or performing other jobs necessary to complete the adventure (voyage).

\section{The Island of Rhode}

The Island of Rhodes is a forefront island around $80 \mathrm{~km}$ in length and an average width of about $38 \mathrm{~km}, 1,400$ square kilometers area having a coastline of 220 kilometers approximately. The longer coastline and its features support the sea harboring and trading. Being situated in the shipping routes from west Europe, Africa and Asia to Aegean Sea, Dardanelles and Black Sea, the island, had been historically of much importance. The island is located in Latitude: $36^{0} 10^{\prime}$ North and Longitude: $028^{\circ} 00^{\prime}$ East, in the North Eastern extreme of Mediterranean Sea, South East of the Aegean Sea and the famous Island of Crete or "Kriti" lying on WestSouth-West of the Rhodes. The island lies in the passage to Aegean Sea and Black Sea. It is situated in close proximity of the Levant which had been an important market between east and west. The island and its commercial significance highly influenced the maritime commerce and trade by sea in the Mediterranean region. 


\section{Levant and Maritime}

The term 'Levant' refers to the old region including countries of the eastern Mediterranean region South-East of Greece and Turkey. Some authors refer it as the area from Cyprus to parts of southern Turkey. Others differ and are of the opinion that 'Levant' historically covers the region which includes mainly Syria, Lebanon and Palestine. Presently, it includes Jordan, the West Bank (now under Israeli occupation) and Israel itself (Siddiqui, 2014).The later interpretation appears correct as the similar region was termed 'Bilad e Sham' or 'left hand region' in the Muslim and Arab history. The name Bilad e Sham was given by Arabs of Hejaz who conquered the region in $7^{\text {th }}$ Century CE. Levant has been a center of trade and commerce between East and West. It was known to the people of Asia to the extent of China in the East and entire Europe in the west. Trading was both by sea and land. The region of Levant contributed considerably in development of trade and commerce especially in the international maritime trade.

\section{Athens and Maritime}

During $5^{\text {thand }} 4^{\text {th }}$ century B.C. the naval supremacy of Athens remained unchallenged in the entire region. By virtue of such power, the Athenian Empire strongly dominated the commerce and trade by sea in the Mediterranean region especially the Aegean Sea. The port of Piraeus with three harbors played central role in harboring ships, both local as well as foreign ships. More significantly, in view of massive maritime trade activities, it introduced and developed the practice of writing agreements for employment of ships for carriage of goods and transportation of passengers. The security available with written agreements and effective system of resolving the disputes efficiently, a new system of maritime (previously named naval) loans was introduced. The special features of such loans, in addition to high interest rates, included the covering of risks by repayments becoming due only on successful completion of the voyage with the ship and cargo as security for loans. To facilitate the maritime activities, Athenian's empire, introduced a system of 'special commercial maritime courts' dikaiemporikai, which were distinct from civil courts and had unique procedures like summary courts for quick and timely resolution of commercial disputes especially maritime disputes. Such courts resembled as parts of the administrative authorities and officials of the ports with juridical features. In the circumstances where foreigners had no rights at all or too little rights available for seeking justice, these courts in contrast were open for foreign individuals or entities. Unlike traditional courts, special provisions were available for compelling a defendant to appear in the trial. Special and effective mechanism was available for enforcing the judgments of naval/maritime tribunals. The proceedings and executions were effective and timely, without discrimination of nationality and rigors. Usually 30 days' time was available to thecourts to decide a matter before it. It can be safely assumed that the Athenian maritime practices paved way for modern maritime activities and maritime and admiralty laws. The jurisdiction of these courts included the contracts made in Athens on maritime trade within the empire and to foreign destinations. The case law from these courts formed precedents for later adjudications (Cohen, 2005). The effectiveness and business of a 
port mainly depends upon its location, natural sheltering, and trading activities in the area especially willingness, availability and interests of merchants. The port of Athens having all these properties proved as a successful and effective port in the region. Athenian dominance in the naval and maritime affairs continued for around five centuries from $8^{\text {th }}$ century to $4^{\text {th }}$ century B.C. These model courts later adopted by the Roman Empire and played significant role in establishing maritime commercial activities in the region and across the region to England and other countries.

\section{Conclusion and Recommendations}

Maritime practices developed from needs of the societies only in the civilized world where security to ships and their loads were available. It certainly brought prosperity and enhanced commercial activities in the areas supporting commerce and trade. In simple, maritime commerce basically involves two elements, a ship and its owner as carrier and a merchant importing or exporting goods by sea. A ship owner as carrier is mainly concerned with security and safety of his ship when calling a foreign port. He expects smooth and peaceful operations of his ship and equitable services in consideration of the taxes levied from him and moneys paid for necessities. A ship owner always avoids from calling ports where his ship may be detained unduly, fined or delayed. Similarly, a merchant importing or exporting goods expects a smooth and peaceful atmosphere where he could load or discharge the good without difficulties, clear them through the customs and market or export them. Therefore, a port receiving or dispatching goods necessarily requires smooth and peaceful commercial and operational atmosphere. Disputes arising between private parties or with officials of the port or revenue authorities necessarily require to be handled and dealt with equitably and justifiably without delays and any influence in a fair and commercial manner.

Maritime education must be introduced in educational institutions at Bachelor level as optional subject. Legal institutions imparting legal education must include and make efforts to deliver Maritime and Admiralty education in law. Universities should make arrangements for workshops, seminars, publications and short courses to introduce the maritime sector and its importance in national economy. 


\section{References}

Administration of Justice 1956 https://www.legislation.gov.uk/ukpga/1956/46/pdfs/ukpga_19560046_en.pdf

Admiralty Jurisdiction of High Courts Ordinance 1980 http://www.ahmedandqazi.com/actsandregulations/shippingLaws/theAdmir altyJurisdictionHighCourtsOrdinance\%201980.pdf.

Azhar Ahmad Khan and Others v. M.V. Ashar and 3 Others PLD 1985, 278, Quetta 12

Benedict, E. (1940). Admiralty: Baker, Voorhis \& Co

Britannica, E. (1993). History of Ships, Encyclopedia Britannica https://www.britannica.com/technology/ship/History-of-ships.

Britannica, E. (1993). Maritime Law, Encyclopedia Britannica https://www.britannica.com/topic/maritime-law.

Cohen, E. E. (2005). Ancient Athenian maritime courts. The Law book Exchange, Ltd.

Flower, H. I. (2014). The Cambridge companion to the Roman republic. Cambridge University Press.

Garner, B. A. (2004). Meaning of Maritime, Black's law dictionary: West General Clauses Act $1897 \quad$ https://www.malaw.org.pk/pdflaw/General\%20Clauses\%20Act\%201897.pdf.

International Regulations for Preventing Collisions at Sea 1972 http://www.mar.ist.utl.pt/mventura/Projecto-Navios-I/IMOConventions\%20(copies)/COLREG-1972.pdf.

Lakhra Power Generation Company Limited (LPGCL) v. Karadeniz Powership Kaya Bey, 2014 CLD 337

Siddiqui, M.A. (2014, June 17). What is Levant? Dawn https://www.dawn.com/news/1113209. 